\title{
The Urban Stream Syndrome - a Mini-Review
}

\author{
Dana Komínková* \\ CTU in Prague, Faculty of Civil Engineering, Department of Sanitary and Ecological Engineering, Thakurova 7, 16627 \\ Prague 6, Czech Republic
}

\begin{abstract}
This paper reviews various impacts of urbanization on rivers and streams, which lead to symptoms summarized by the general term "urban stream syndrome". Growing areas of impervious surfaces cause deterioration of water recipients flowing through urban areas. The symptoms of deterioration usually include altered chemical parameters of water and sediment, accumulation of priority pollutants in aquatic biota, changes in biological composition of the aquatic biota (lower biodiversity, changing abundance) and altered runoff regime of recipients (artificial floods versus extremely low flows). The paper concludes that restoration is the only way to achieve good ecological status (health) of the waterways. The restoration has to focus on measures to decrease the effective imperviousness and increase the retention and later local use of the water. The paper also highlights that effective management of urban streams includes social, economic, and political dimensions and requires a broader view beyond the traditional stream ecology.
\end{abstract}

Keywords: Urban creek, urban drainage, urban stream syndrome, impervious surface.

\section{INTRODUCTION}

Maintaining an adequate water supply and protecting water quality in urbanized areas are growing problems whose solutions will require extensive effort and research. Urban environment does not only affect the water quality by a continuously growing input of anthropogenic substances, but mainly changes the hydrological cycle via increasing amount of impervious surfaces in catchments. Urban drainage is on one hand an essential part of urban sanitation, but at the same time one of the main causes of stream deterioration. Urban streams are highly vulnerable to impacts associated with land use changes resulting from the increasing urbanization [1-4]. Streams play an important role in the urban areas as 1) carriers of water and suspended solids; 2) habitats for diverse and productive biota, and 3) social and cultural elements for human inhabitants living in the catchment [5]. The impact of anthropogenic activities on streams has substantially increased during the recent years, and the streams are losing their natural character rapidly. The increasing number of affected streams has attracted the research communities and motivated them to address the problem of urban streams.

The main effects of urbanization on runoff and floods have been addressed since the late1960's [6-8]. More recent studies have focused on the engineering aspects of watersheds, (e.g., detention basins, riparian buffers and septic systems, [9-14] and their influence on runoff amount and water quality [15-17]. The recently adopted term "urban stream syndrome" [5] summarizes the degradation of

*Address correspondence to this author at the CTU in Prague, Faculty of Civil Engineering, Department of Sanitary and Ecological Engineering, Thakurova 7, 166 29, Prague 6, Czech Republic; Tel: +420 224355 447; Fax: +420 224355 474; E-mail: kominkova@fsv.cvut.cz streams in urban areas, characterized by flashier hydrograph, changes of channel stability and morphology, deterioration of water and sediment quality and changes of the ecological status/ecological health of the recipients.

The objective of the paper is to summarize the impact of urbanization on streams and the most common effects related to deterioration of urban streams. In addition, new trends and methods to restore a good ecological status of urban streams are reviewed. The focus of the paper is primarily on small streams in urban areas, because they are the most abundant of receiving waters and because, with the small catchments, they are very sensitive to land use changes. The response of small streams to land use changes can serve as a warning signal of the potential deterioration to downstream waters. Equally, the protection of small stream ecosystems will support the protection of large receiving waters downstream [18].

\section{THE CONCEPT OF "URBAN STREAM SYNDROME"}

The symptoms of the urban stream syndrome include a flashier hydrograph, elevated concentration of nutrients and contaminants, altered channel morphology and reduced biodiversity $[5,15]$. These effects are often accompanied by other symptoms which are not observed in all urban areas, such as reduction of baseflow and increase of suspended solids concentration. Although most of the symptoms show consistency in their occurrence in urban areas worldwide, their degree to which they change the aquatic ecosystems is highly variable and depends on local conditions. The main symptoms are summarized in Table $\mathbf{1}$.

The mechanisms driving the syndrome are integrated and variable, but most of the impacts result from a few major large scale sources, particularly from urban storm water runoff delivered to stream by hydraulically efficient drainage 
Table 1. Symptoms Associated with the Urban Stream Syndrome (Modified from [5, 15] (*Correlation with Level of Urbanization was not Clearly Proved)

\begin{tabular}{|c|c|}
\hline Feature & Symptom \\
\hline \multirow{6}{*}{ Hydrology } & Increasing frequency of overland flow \\
\hline & Increasing frequency of erosive flow \\
\hline & Increasing magnitude of high flow \\
\hline & Decreasing lag time to peak flow \\
\hline & Increasing rise and fall of storm hydrograph \\
\hline & Changes of baseflow magnitude * \\
\hline \multirow{5}{*}{ Water and sediment chemistry } & Increasing concentration of nutrients $(\mathrm{P}, \mathrm{N})$ \\
\hline & Increasing concentration of toxic substances \\
\hline & Increasing temperature \\
\hline & Increasing concentration of suspended matter \\
\hline & Decrease of organic matter retention \\
\hline \multirow{7}{*}{ Channel morphology } & Increasing channel width \\
\hline & Increasing pool depth \\
\hline & Decreasing stability of the channel \\
\hline & Increasing scour \\
\hline & Disturbance of the river continuity $*$ \\
\hline & Changes in sedimentation processes * \\
\hline & Enrockment of banks \\
\hline \multirow{4}{*}{ Fish } & Decreased number of sensitive species \\
\hline & Increase of tolerant species* \\
\hline & Changes of abundance* \\
\hline & Changes of biomass* \\
\hline \multirow{3}{*}{ Invertebrates } & Increased number of tolerant species \\
\hline & Decreased number of sensitive species \\
\hline & Decreased number of predators* \\
\hline \multirow{4}{*}{ Algae } & Increased number of eutrophic diatoms \\
\hline & Decreased number of oligotrophic diatoms \\
\hline & Changes of biomass* \\
\hline & Presence of toxic algae \\
\hline \multirow{5}{*}{ Ecosystem processes } & Decrease in nutrition uptake \\
\hline & Leaf breakdown \\
\hline & Net ecosystem metabolism* \\
\hline & Nutrition retention \\
\hline & Production : Respiration ratio \\
\hline
\end{tabular}

system [5]. Other stressors include combined sewer overflows (CSO), waste water treatment plant (WWTP) effluent, legacy pollutants (long-lived pollutants from earlier land use), and illegal discharges of waste water. Most of the research on urban drainage impacts has focused on correlations between stream chemical and biological metrics and various topographical or hydraulic parameters, such as total catchment imperviousness, distance between stream reach and urban land and hydraulic efficiency of the sewer system.

\section{HYDROMORPHOLOGICAL CHANGES}

Increasing amount of impervious surfaces and decreasing area of natural vegetation cover belong to the most pronounced characteristics of urbanization. These changes significantly alter the hydrological conditions in the catchment and the behaviour of streams. The high amount of impervious surfaces causes a substantial increase of surface runoff components, along with a decrease of groundwater recharge and base flow. 
The amount of water entering the recipient during rain events causes increase of flow, where the hydrographs of these events tend to be more "flashy". The rising and falling limbs of the hydrograph are steeper and the maximal flow often exceeds the natural maximum flow from pre-urbanized period. Storm waters quickly drained during rain events by conventional sewer do not reach the aquifers and therefore the base flow is lower than the natural groundwater discharge from aquifers to streams [19].

The increasing volume and frequency of high flow requires stronger flood protection and mitigation of negative flood impact on the ecological integrity of the receiving streams and their inundation zones [19].

The construction of sewer systems also results in alternation of the catchment area and the stream length. These changes are manifested directly as a shift in the surface runoff volume, and indirectly in shortening the critical duration of rain and increase the intensity of the design rain. The urbanization causes higher flood frequency [15]. While in natural catchments the flood periodicity is 1.2-2.4 years, in urban catchment the flood may occur several times a year $[19,20]$. Increase of the recurrence interval of flood flows causes higher erosion and hence enlargements of stream channels.

The current flooding zone may therefore not correspond with flooding zones reported in the history for the same recurrence interval $[19,20]$.

Urban streams are often dammed by artificial reservoirs and steps, which may cause significant channel straightening and disturbance of the movement of organisms. As a consequence, large segments of the streams are becoming impassable for aquatic organisms. The impact on aquatic biota due to enlargement of stream channels is particularly pronounced during drought or decrease of the stream water level. Conversely, an enhancement of maximal flow decreases the channel stability and increases the risk of erosion. This results in alternation of stream morphology, loss of the bank environment, and lower water quality caused by high amount of suspended solids and siltation of the channel. The morphological change of the streams inhibits natural succession of aquatic biota and destroys natural habitats $[4,15,21]$.

\section{CHEMICAL AND PHYSICAL CHANGES}

The quality of aquatic environment in urban areas is affected by waste water entering the stream from the system of urban drainage (combine sewer overflows, storm water drains, waste water treatment plant effluents, illegal discharges). The input of waste water usually alters the water and sediment quality and causes changes to the chemical status of the recipient.

During dry weather, receiving waters are mostly affected by wastewater treatment plant (WWTP) effluents or other continuous sources. The impact on receiving waters depends in this case on the treatment efficiency of WWTP and the level of dilution. In contrast, the quality of the aquatic environment during wet weather is affected not only by WWTP, but mostly by direct surface runoff, storm water drain (SWD) and combine sewer overflow (CSO). The rainwater and surface flow water contain insoluble substances, organic micropollutants and toxic metals from traffic, local heating systems and commercial and industrial sources [22]. These substances accumulate during dry-weather periods on the land surface and are washed off during rain events. The water entering the recipients from CSO-outfalls is a mixture of rainwater, municipal sewage, industrial wastewater and sediment (sewer sludge) accumulated in the sewer system during dry periods. The winter surface runoff can also contain high amounts of salts and insoluble substances [23].

The water quality in receiving waters decreases during rain events, with negative impacts on aquatic biota. One of the basic chemical parameters, $\mathrm{pH}$, is very often affected during rain events. $\mathrm{pH}$ in water impacted by CSO can increase during rain events due to higher concentrations of ammonia from ammonium ions in the sewer systems. In turn a decrease of $\mathrm{pH}$ is often observed in small creeks affected by SWDs where the discharge of SWD into the creek may exceed the creek flow rate above the discharge point [24]. The decrease of $\mathrm{pH}$ (below 6) affects the mobility of pollutants, especially toxic metals, which become more mobile and bioavailable to aquatic organisms [25-27]. Rain events also contribute to elevated concentration of suspended solids, which decrease the ecological status of aquatic biota (plants by low level of light, fish by sedimentation of suspended solids in gills).

The pollution by organic matter often causes oxygen depletion and changes in redox conditions of the aquatic environment. Changes in the redox potential may cause remobilization of metals and other pollutants from sediment and hence increase their bioavailability [14]. Insufficient concentration of dissolved oxygen increases negative effects of toxic substances on aquatic biota. Beside $\mathrm{pH}$ and redox potential, the partitioning behaviour and spatial distribution of pollutants in the aquatic environment is also regulated by hydrodynamics, biogeochemical processes and other environmental conditions, such as salinity, temperature and particle size distribution of sediments [28]. Changes in sediment chemistry due to bottom disturbance can result in remobilization of contaminants. Subsequently, exposure to different chemical conditions could result in desorption and transformation of contaminants into more bioavailable or toxic chemical forms [29]. The fate of toxic metals and other priority pollutants in the urban creeks environment can lead to higher uptake of pollutants by aquatic biota. Concentrations of priority pollutants (mainly toxic metals, $\mathrm{PAH}, \mathrm{PCB}$, etc.) in sediments usually exceed those in overlying water by three to five orders of magnitude [27, 30,31]. Higher concentrations of suspended matter enlarge the risk related to presence of toxic substances adsorbed on surface of the solid particles (e.g. toxic metals). Runoff from roads and agriculture area is often enriched by nitrates and nitrites (they are toxic for fish), sulphates, which are affecting the calcium carbonate equilibrium and consequently they are affecting hydrochemical stability and agressivity of water. Surface flow from roads may increase concentration of carcinogenic polycyclic aromatic hydrocarbons (PAH), known for high stability and ability to accumulate in sediments, and nonpolar hydrocarbons substances from petrol, accumulated in organisms and sediments and highly toxic to zooplankton.

The pollution load is closely related to the rain characteristics. Sobota [20] stated that $90 \%$ of the COD input is asso- 
ciated with the beginning of intensive rain $(15-20 \%$ of rain duration) - first flush. In the case of less intensive rains, the increase of pollution concentration is delayed and less rapid.

A big attention has been paid to endocrine disruptors in municipal waste water, typically caused by low efficiency of WWTP to remove these substances [32]. These substances enter water recipients already in very small concentrations may cause endocrine disruption in aquatic biota such as changes in the ratio of sex of the population and other serious effects, mainly in fish. The stability of the whole biotic community may therefore decrease substantially.

Another physical factor negatively affecting water recipients is increasing temperature caused by warmer surface runoff from impervious surfaces, missing bank vegetation and also proximity of buildings with light reflection. The heat may change the temperature regime of the stream, because the stream temperature increases and the periods of natural cold become shorter [19].

\section{CHANGES OF THE BIOLOGICAL COMPONENT OF THE AQUATIC ENVIRONMENT}

The stream ecosystem is a closed complex, where each part has its own function. The aquatic biota is composed by different types of organisms, producers (phytoplankton, macrophytes), consumers (zooplankton, invertebrates, fish) and decomposers (bacteria, fungi). Loss or restriction of one of the group will cause collapse of the whole ecosystem. The biota is affected by both the water quality and quantity. Water quality directly affects the abundance (population density), reproduction, and survival, ratio of sex, age structure and, in particular, the long term biodiversity. The aquatic organisms are used as indicator/ bioindicator, of water quality. The most common group of bioindication organisms are fish, macroinvertebrates and diatoms. Especially diatoms and macroinvertebrates are very good indicators of urban drainage impact [5, 33, 34].

The impact of water quantity in urban areas is affected by the level of urbanization and amount of impervious surfaces. In the past, the question of water quantity was mostly focused on minimal flow $\left(\mathrm{Q}_{355}\right.$ - flow reached 355 day a year), although this concept cannot be fully applied in urban catchments. The minimal flow in urban streams is often not maintained, especially during dry months, whereas the surface runoff during rain events is drained to the stream and the maximal acceptable flow is frequently exceeded [35]. Exceeding of the maximal flow causes washout of organisms not resisting against such a high flow [2, 5, 35]. In this case the whole food chain is dislocated, and the recolonization of the community requires several weeks or months. In case of frequent summer rains, the disturbance repeats before the biota can recover $[2,35]$.

\section{URBAN STREAM SYNDROME AND NEW TRENDS IN URBAN WATER MANAGEMENT}

Urban streams have the potential to provide precious natural resources to humans who live in their catchments [16]. In many cities of the world this potential has not been fully acknowledged, because streams in most urban areas were transformed into drains or sewers. The primary goal of the urban waterway management for most of the $20^{\text {th }}$ century was protection of humans from floods and diseases. Although this goal remains the first priority, traditional approaches to waterway management for public health and safety have often applied at the expenses of the other goals, such as public amenity and ecosystem health [5]. New approaches in urban design and waterway management show great potential for achieving all goals of public safety, amenity, and improved ecological conditions in streams [36] of many urban areas [37].

Restoration of waterways has become an important tool of the water management during the last decade, and it remains crucial for improvement of ecological conditions of streams. Restoration of waterways is not a new tool in water management; however, innovative approaches are needed to understand the waterway's functioning with positive effects on the restoration.

The first step of restoration is a clear identification of the target state of the stream/river to be achieved, and the second step focuses on the identification of control indicators. Currently these indicators mostly express the quality of the aquatic biota, e.g. biodiversity and abundance. Future innovative parameters should indicate the function of the aquatic ecosystem, such as gross primary production, respiration of the community, etc. [38].

The restoration measures to improve the ecological status of urban streams are short term and long term. The group of short term measures includes embankment, planting of bank vegetation (not a native one), pollution source control, fish pass, and construction of remedial measures directly in the stream channel. The end-of-pipe strategy measures such as retention and detention reservoirs are also included. The short term measures provide solution for acute problems typical for urban streams channels, but they do not provide increased biological diversity of the aquatic community in the long term perspective. These measures do not respect the catchment runoff processes, are also highly demanding on continuous maintenance and therefore may become financially unacceptable. The long term measures respect the catchment processes at their real scale and therefore are selfmaintained. These measures include changes in land use, creation of buffer zones along the streams, restoration of hydrological conditions (infiltration of stormwater, decrease of effective imperviousness), rehabilitation of natural bank vegetation and support of its natural zonation and restoration of the connection between flood plain and the stream channel [39].

Numerous papers [16, 38 40-43] had identified the basic problem of urban streams restorations, but many studies are based on knowledge an experiences obtained in restoration of waterways in rural areas, where the stressors affecting the streams and the responses of the aquatic ecosystems are different. Most of the earlier studies focused on long term results of restoration were conducted on streams affected by mining activity or discharge of toxic substances. The applicability of such results to the urban streams restoration is very limited.

Presently, the chemical and toxicological effects on waterways are minimized by high requirements on waste water 
treatment efficiency and construction and operation of sewer system. The construction of sewer system prefers separated sewer or reconstruction of combine sewer overflows to maintain minimal impact of the overflows water on the recipient. Because the current pollution control addresses dominantly the source, the main goal of the urban stream restoration is not the elimination of chemical impact, but successful management of big volume of storm water from sewer system and impervious areas. Numerous studies [5, $33,38,43,44]$ showed that restoration at local scale focused on increasing diversity of habitats typically does not bring the anticipated improvement of the biodiversity. In turn, better results are achieved by restoration of the waterways focused on the primary source $[5,3343,44]$. A combination of applied measures in catchments together with rehabilitation of the channels and bank areas has been proven more successful and sustainable [5, 33 43, 44]. Although the importance of the catchment processes for restoration is well known, it is still neglected in many management concepts. This marginalization leads to the overuse of end -of- pipe strategies for stormwater management $[5,15]$ that apply measures such as retention, sedimentation reservoirs, ponds and artificial wetlands directly on the waterway or sewer system. Application of these measures is often carried out without good understanding of the basic processes between hydrological changes and biota (hydraulic stress for biota, periodicity of flood occurrence, periodicity of pollutants load, etc.) [5, 15]. Application of the end -of- pipe strategies achieved in many cases a decrease of the maximal flow and a transformation of the flood [45], but the stress for biota did not decrease. These strategies do not preserve the natural periodicity of floods, and although they maintain a lower runoff during the rain event, they do not change the anthropogenic induced periodicity of flood [5, 34, 44].

According to recent research, a successful remediation of urban streams can be achieved through widespread application of innovative approaches to drainage design. The complex approaches $[1,33,34]$ propose to decrease the effective impervious areas in the first step, followed by retention and local use of the stormwater instead of direct drainage to stream. This strategy is finally complemented by rehabilitation of the creek channel to support a greater diversification of habitats.

The restoration of urban streams cannot return the streams back to the natural status, but it should ensure the recovery of the basic functions of the ecosystem and provide an acceptable compromise between the ecosystem and local human communities. Schauman and Salisbury [43] proved that heavily modified urban creeks have negative effect on local inhabitants. The study also showed that a waterway restoration which is not in agreement with requirements of the local community is not long-term sustainable. Effective management of urban streams will require a broader perspective beyond the traditional stream ecology, taking into account social, economic, and political dimensions [5].

\section{CONCLUSIONS}

The review of symptoms of the urban drainage syndrome and past and present urban water management strategies showed that urban streams have to be particularly understood as integral part of urban environment. It also showed that restoration (renaturalization, unchannelization) is the only way to achieve good ecological status (health) of the waterways. After decades of deterioration of urban waterways' ecological status (channelization, pollution, etc.); the restoration to conditions allowing the use of urban waters as place for recreation is expected to be a long-term process. It was further concluded that restoration of urban creeks needs to follow different rules than restoration of creeks in rural areas. Only a source-focused restoration of channels of urban creeks and rehabilitation of physical habitats for aquatic biota will provide the expected increase of biodiversity. Because the poor ecological status of urban streams is typically caused by floods induced by runoff from impervious surfaces due to progressing urbanization, the most promissing strategies are based on decrease effective imperviousness and application of measures to increase retention and later local use of the stormwater. Finally, the restoration of urban creek is not possible without good understanding and communication between engineers, architects, city planner and natural scientists.

\section{CONFLICT OF INTEREST}

The authors confirm that this article content has no conflicts of interest.

\section{ACKNOWLEDGEMENTS}

This works was supported by the project of Ministry of Education of CR No. MSM 6840770002 and projects n. SGS12/131/OHK1/2T/11 and SGS11/039/OHK1/1T/11. The comments of all the reviewers are highly appreciated.

\section{REFERENCES}

[1] Feminella JW, Walsh CJ. Urbanization and stream ecology: an introduction to the series. J North Am Benthol Soc 2005; 24(3): 585-7.

[2] Komínková D, Stránský D, Št’astná G, Caletková J, Nábělková J, Handová Z. Identification of Ecological Status of Stream Impacted by Urban Drainage. Water Sci Technol 2005; 51 (2): 249-56

[3] Nábělková J, Komínková D, Št’astná G. Assessment of ecological status in small urban streams of Prague agglomeration. Water Sci Technol 2004; 50 (5): 285-91.

[4] Št'astná G, Kabelková I, Nábělková J, Stránský D. Interactions of an impounded stream with urban drainage. International Symposium on New Directions in Urban Water Management. Paris: France 2007

[5] Walsh CJ, Roy AH, Feminella JW, Cottingham PD, Groffman PM, Morgan II RP. The urban stream syndrome: current knowledge and the search for a cure. J North Am Benthol Soc 2005; 24(3): 70623.

[6] Leopold LB. Hydrology for urban land planning - a guidebook on the hydrologic effects of urban land use. US Geological Survey Circular. USA: U.S. Government Printing Office 1968; p. 554, [cited 2012 September 1]

[7] Seaburn GE. Effects of urban development on direct runoff to East Meadow Brook, Nassau County, Long Island, New York. US Geological Survey Professional Paper. 1969; pp. 627-B, [cited 2012 September 1]

[8] Anderson G. Effects of urban development on floods in Northern Virginia. US Geological Survey Water-Supply Paper. 1970; 2001C, [cited 2012 September 1]

[9] Robertson WD, Cherry JA, Sudicky EA. Ground-water contamination from two small septic systems on sand aquifers. Ground Water 1991; 29: 82-92.

[10] Griffin CB. Uncertainty analysis of BMP effectiveness for controlling nitrogen from urban nonpoint sources. Water Resour Bull 1995; 31: 1041-50. 
[11] Chin A, Gregory KJ. Urbanization and adjustment of ephemeral stream channels. Ann Assoc Am Geogr 2001; 91: 595-608.

[12] Booth DB, Hartley D, Jackson R. Forest cover, impervious-surface area, and the mitigation of stormwater impacts. J Am Water Resour As 2002; 38: 835-45.

[13] Rose S, Peters N. Effects of urbanization on streamflow in the Atlanta area (Georgia, USA): a comparative hydrological approach. Hydrol Process 2001; 15: 1441-57.

[14] Burns D, Vitvar T, McDonnell J, Hasset J, Duncan J, Kendall C. Effects of suburban development on runoff generation in the Croton River basin, New York, USA. J Hydrol 2005; 311: 266-81.

[15] Komínková D, Handová Z, Nábělková J, Caletková J. Syndrom urbanizovaných toků a nový pohled na revitalizaci městských toků (Urban stream syndrome and new approach to urban stream rehabilitation). Vodní hospodářství 2007; 57(2): 39-42.(in Czech).

[16] Meyer JL, Paul MJ, Taulbee WK. Stream ecosystem function in urbanizing landscape. J North Am Benthol Soc 2005; 24(3) : 60212.

[17] Paul MJ and Meyer JL. Streams in the urban landscape. Annu Rev Ecol Syst 2001; 32: 333-65

[18] Walsh CJ, Leonard AW, Ladson AR, Fletcher TD. Urban stormwater and the ecology of streams. Cooperative Research Centre for Freshwater Ecology and Cooperative Research Centre for Catchment Hydrology. Canberra 2004.

[19] Pollert J, Komínková D, Handová Z, et al. Dopad povodní na technickou a ekologickou stabilitu drobných městských toků. (Impact of floods on technical and ecological stability of small urban creeks), Final report of project n. GAČR 103/03/Z017, CTU, Prague 2004.(in Czech)

[20] Sobota J. Kvantitativní a kvalitativní aspekty deštových srážek různé intenzity a možnosti omezení jejich negativních vlivů na povrchové toky (Quantitative and Qualitative aspects of rain events of different intensity and possibilities to minimize negative effect on surface waters). Final report of the project PPŽP/510/4/97, VÚV TGM Prague 1997. (in Czech)

[21] Komínková D, Caletková J, Nábělková J, Št’astná G. Vliv urbanizace na ekologický stav drobných toků (Impact of urbanization on ecological status of small streams). Final report of the project GACR n.205/05/0426, CTU, Prague 2007. (in Czech)

[22] Gasperi J, Gromaire MC, Kafi M, Moilleron R and Chebbo G. Contribution of wastewater runoff and sewer deposit erosion to wet weather pollutants loads in combined sewer systems. Water Res 2010; 44: 587586.

[23] Marsalek J. Road salts in urban stormwater: an emerging issue in stormwater management in cold climates. Water Sci Technol 2003; 48(9) : 61-70

[24] Karlavičiene V, Švediene S, Marčiulionine DE, Randerson P, Rimeika $\mathrm{M}$ and Hogland $\mathrm{W}$. The impact of storm water runoff on a small urban stream. J Soil Sediment 2009; 9: 6-12.

[25] Calmano W, Hong J, Förstner U. Binding and mobilization of heavy metals in contaminated sediments affected by $\mathrm{pH}$ and redox potential. Water Sci Technol 1993; 8-9: 223-35.

[26] Komínková D. Vliv městského odvodnění na bioakumulaci těžkých kovů (Impact of urban drainage on bioaccumulation of toxic metals). Habilitation thesis, CUT, Prague 2006. (in Czech)

[27] Nábělková J. Těžké kovy v prostředí drobných urbanizovaných toků (Heavy metals in the environment of small urban streams). Ph.D. Thesis, CUT. Prague 2005 (in Czech)
[28] Cantwell MG, Burgess RM and Kester DR. Release and phase partitioning of metals from anoxic estuarine sediments during period of simulated resuspension. Environ Sci Technol 2002; 36: 5328-34.

[29] Eggleton J, Thomas KV. A review of factors affecting release and bioavailability of contaminants during sediment disturbance events. Environ Int 2004; 30: 973-80.

[30] Bryan GW, Langston WJ. Bioavailability, accumulation and effects of heavy metals in sediment with special references to United Kingdom estuaries: a review. Environ Pollut 1992; 76: 89-131.

[31] Komínková D, Nábělková J. Effect of urban drainage on bioavailability of heavy metals in recipient. Water Sci Technol 2007; 56 (9) : 43-50.

[32] Aurriol M, Filali-Meknessi Y, Tyagi RD, Adams CD, Surampalli RY. Endocrine disrupting compounds removal from watewater, a new challenge. Process Biochem 2006; 41: 525-39.

[33] Booth DB. Challenges and prospects for restoring urban streams: perspective from the Pacific Northwest of North America. J North Am Benthol Soc 2005; 24(3): 724-37.

[34] Walsh CJ, Fletcher TD, Wong THF, Breen PF. Developing predictive ecological capacity for stormwater management decisionmaking framework. $3^{\text {rd }}$ Australian Stream Management Conference, Brisbane, 2001.

[35] Caletková J. Ekologicky vhodné rozmezí průtoků pro makrozoobentos $\mathrm{v}$ tocích ovlivněných městským odvodnění (Identification a range of ecological acceptable dicharge), Ph.D thesis, CTU, Prague, 2007. (in Czech)

[36] Directive 2000/60/EC of the European Parliament and the Council of 23 October 2000 establishing a framework for Community action in the field of water policy.

[37] Lloyed SD, Wong THE, Porter B. The planning and construction of an urban stormwater management scheme. Water Sci Technol 2002; 45(7):1-10

[38] Hart BT, Maher B, Lawrence I. New generation water quality guidelines for ecosystem protection. Freshwater Biol 1999; 41, 347-359.

[39] Buffington JM, Woodsmith RD, Booth DB, Montgomery DR. Fluvial processes in Puget Sound rivers in the Pacific Northwest. In Restoration of Puget Sound river. Seattle: University of Washington Press 2003

[40] Hammer DA. Creating Freshwater Wetlands, $2^{\text {nd }}$ ed. Boca Raton, Florida: CRC Press 1997.

[41] Kadlec RH, Knight RL. Treatment Wetlands. Lewis Publishers, Boca Raton, Florida; 1996

[42] Duncan HP. An Overview of Urban Stormwater Quality. $24^{\text {th }} \mathrm{Hy}$ drology and water resources symposium. Auckland, New Zealand, 1997; 143-8.

[43] Schauman S, Salisbury S. Restoring nature in the city: puget sound experience. Landscape Urban Plan 1998; 42: 287-95.

[44] Walsh CJ, Breen PF. Urban stream rehabilitation through a decision-making framework to identify degrading processes and prioritize management action. 2nd Australian Stream Management Conference Proceedings 1999; pp. 673-8.

[45] Stránský D, Fatka P. Posouzení systému odvodnění sídliště Košík při zatižení extrémními dešt’ovými srážkami (Evaluation of the urban drainage system of Košík housing estate during extreme rain events). In: Sborník př́spěvků konference Nakládání s dešt’ovými vodami ve městech a obcích. Prague; Aquion, 2004; pp. 154-9. (in Czech).

(c) Dana Komínková: Licensee Bentham Open.

This is an open access article licensed under the terms of the Creative Commons Attribution Non-Commercial License (http://creativecommons.org/licenses/ by-nc/3.0/) which permits unrestricted, non-commercial use, distribution and reproduction in any medium, provided the work is properly cited. 